DOI 10.31558/2307-2318.2018.4.5

УДК: 338.001 .36

Барткова К.М., студентка, ДонНУ імені Василя Стуса

Андронік О.Л., к.е.н., доцент кафедри підприємництва, корпоративної та просторової економіки, ДонНУ імені Василя Стуса

\title{
ПОДАТКОВА СИСТЕМА ЯК ІНСТРУМЕНТ НА ШЛЯХУ ДО СТАБІЛЬНОСТІ ЕКОНОМІКИ
}

У даній статті проаналізовано основні зміни та сучасний стан податкової системи України й визначено слабкі сторони та недоліки діючої системи також виокремлено стратегічні помилки, яких припустився уряд при внесені змін та поправок до Податкового Кодексу України. На основі порівняння позицій української системи оподаткування в міжнародних рейтингах розроблено ряд пропозицій, що покращать мікроклімат всередині країни та сприятимуть зростанню приватного сектору в економіці, відповідно до досвіду успішних країн. Значну частину уваги приділено пільговому оподаткуванню сільськогосподарських суб'єктів, а також спрощеній системі оподаткування малих та середніх підприємств, сформовано основні принципи реформування спрощеної системи та окреслено основні недоліки оподаткування в даних сферах. Проаналізовано вигідність становлення нульового корпоративного податку та оподаткування прибутку підприємства. Сформовано податкові стимули, що допоможуть збільшити інвестиційну привабливість українських підприємств для інвесторів не тільки всередині країни, а й іноземних. У порівнянні з іншими країнами пострадянського простору в Україні часу на подання всіх необхідних документів витрачається найбільше, саме тому у статті згадується про важливість відповідного контролю за порушеннями у сфері оподаткування та формування оновленої законодавчої бази для спрощення процедур подання та перевірки усіх звітностей. Якщо уряд зменшить податковий натиск на підприємства, то це забезпечить вихід певної частки економіки з тіні

Ключові слова: система оподаткування, податки, економіка, податкові стимули, податкова реформа, економічна стабільність, міжнародний досвід.

\section{Барткова К.Н., Андроник Е.Л СИСТЕМА НАЛОГООБЛОЖЕНИЯ КАК ИНСТРУМЕНТ НА ПУТИ К СТАБИЛЬНОСТИ ЭКОНОМИКИ}

В статье проанализированы главные изменения и реалии системы налогов Украины и определены слабые стороны и недостатки действующей системи, также стратегические ошибки которые допустило правительство во время принятия изменений и новшеств к Налоговому Кодексу Украины. Разработано ряд предложений, которые улучшат микроклимат внутри страны и будут способствовать росту частного сектора в экономике, на основании опыта других стран. Много внимания обращено льготам в налогообложении сельхоз субъектов, также упрощенной системе налогообложения для малых и средних предприятий, сформировано основные недостатки налогообложения в этих сферах. Проанализировано выгодность нулевых корпоративных налогов и налогов на доход предприятий. Определено налоговые стимулы, которые помогут увеличить инвестиционную привлекательность украинских предприятий для инвесторов, как украинских, так и зарубежных. В сравнении с другими постсоветскими странами в Украине тратится наибольшее количество времени на оформление всех необходимых документов, именно поэтому в статье вспоминается о необходимости контроля в сфере налогообложения и реформирования налогового законодательства для упрощения 
процедур подачи и проверки всех отчетностей. Если правительство понизит давление на предприятия, то это автоматически уменьшит часть теневой экономики.

Ключевые слюва: система налогообложения, налоги, экономика, налоговые стимулы, налоговая реформа, экономическая стабильность, международный опыт.

\section{Bartkova K., Andronik O.}

TAXATION SYSTEM AS A KEY TO ECONOMIC STABILITY

The article analyses major changes and real state of the tax system of Ukraine, determines weak aspects and disadvantages of the current system, defines strategic mistakes that were made by government by upgrading the Tax Codex of Ukraine. According to the global experience there are listed a line of suggestions and advice, based on the positions of Ukrainian tax system in international rankings, in order to stabilise the economy and improve the microclimate within the country. One of the main aspects that were analysed are specific taxes for agricultural enterprises and tax incentives for small and medium sized enterprises in order to determine the weak point in the taxation system in this sphere. Also the article states that minimal corporate and profit taxes is lucrative for a country, as it will increase the investment attractiveness of the business. Among other Post-Soviet union countries, Ukrainian accountants spend the biggest amount of time to fill in and submit all the statements, that's why it is important to reform the order of submitting all the statements so its going to be easier to check them, determine disorder and punish perpetrators. If the government decreases taxes, that will automatically decrease the level of shadow economy.

Key words: tax system, taxation, economy, tax incentives, taxation reforms, economic stability, international experience.

Постановка проблеми. Недосконалість податкового механізму України та повсякчасне внесення поправок до Податкового Кодексу спричиняє неефективність функціонування податкової системи негативно впливає на якість ведення бізнесу та сприяє тінізації економіки. Постійні зміни до законодавства виснажують і малі та середні підприємства, так як податкове навантаження з кожним разом посилюється, а процедура сплати податків постійно ускладнюється.

Для подальшої оцінки та розробки заходів щодо податкової системи України досліджено системи оподаткування Казахстану та Естонії - пострадянські країни, що зуміли ефективно реформувати податкову систему та пристосуватися до ринкової економіки.

Аналіз останніх досліджень і публікацій. Значну увагу податковій системі у своїх роботах приділяли такі вітчизняні науковці В. Андрущенко, А.Бурковська, В.Мельник, А.Соколовська, О.Барановський, та інші. Частково порушення проблем податкової системи у своїх працях торкалися А.Вагнер та А.Сміт.

Мета дослідження. Аналіз тенденцій сучасної податкової системи України, визначення шляхів оптимізації системи оподаткування відповідно до досвіду Естонії та Казахстану.

Викладення основного матеріалу. Податкову систему України можна характеризувати такими явищами як: нерівномірне податкове навантаження на деякі сфери виробництва, нестабільність податкового законодавства та недосконалий механізм контролю та адміністрування.

Стратегічної помилки припустився уряд країни на етапі становлення податкової політики, оскільки багато у чому було скопійовано діючу систему оподаткування європейського зразка, що націлена на розвинені та стабільні економіки країн. 
Ще одним недоліком податкової системи є іiї фіскальний характер здебільшого, так як підприємства змушенні сплачувати податки, а не інвестувати у власний розвиток , що сприяє збільшенню тіньового сектору економіки. В свою чергу зі зростанням тінізації та непрозорості економічних процесів, зменшується дохідна частина бюджету, зростає дефіцит бюджету, що стимулює збільшення податкового тиску на бізнес.

Таблиця 1

Перелік загальнодержавних і місцевих податків та зборів згідно з Податковим кодексом

\begin{tabular}{|c|c|}
\hline \multicolumn{2}{|c|}{ України [11] } \\
\hline Загальнодержавні & Місцеві \\
\hline 1. На прибуток підприємств & 1. Податок на майно \\
\hline 2. На доходи фізичних осіб & 2. Єдиний податок \\
\hline 3. На додану вартість & 3. Туристичний збір \\
\hline 4. Акцизний податок & \multirow{4}{*}{$\begin{array}{l}\text { 4. Збір за місця паркування } \\
\text { транспортних засобів }\end{array}$} \\
\hline 5. Екологічний податок & \\
\hline 6. Рента & \\
\hline 7. Мито & \\
\hline
\end{tabular}

Податкова система країни має переважно короткострокові цілі, такі як наповнення бюджетів державного та місцевого рівнів, та використання коштів на потреби суспільства. До довгострокових завдань податкової політики слід віднести стабілізацію економічної ситуації та забезпечення сталого економічного розвитку та підвищення рівня добробуту населення. Кожні 5 років, новий уряд запроваджував нові реформи, які збилися у сніжний ком і значно обтяжили підприємців податками, зборами та звітностями.

Лише у 2015 році, були внесені поправки та нововведення у податковий кодекс, зокрема у листопаді було скорочено кількість податкових інспекцій вдвічі -3 311 до 161. Також було введено у дію нові сервіси за допомогою яких спрощується система сплати податків - Електронний кабінет платника, Єдине вікно. Такі реформи віщують вибір правильного вектора розвитку податкової системи, готовність економіки до інвестицій та стабілізації.

Система оподаткування в Україні є комплексною та потребує детального огляду, слід відзначити що система оподаткування поділяється на 2 типи:

- спрощена система;

- загальна система.

Загальна система оподаткування передбачає ставку податку на чистий дохід у розмірі $18 \%$ та військовий збір - $1,5 \%$.

Спрощена система оподаткування включає в себе єдиний податок. Єдиний податок - це місцевий податок, який сплачують фізичні та юридичні особи, що знаходяться на спрощеній системі оподаткування. За спрощеною системою оподаткування виділяють єдиний податок за трьома групами:

1. Єдиний податок перша група - 10\% від мінімальної заробітної плати. Максимальний дохід не має перевищувати 300 тис грн за рік та немає бути найманих працівників.

2. Сдиний податок друга група - 20\% від мінімальної заробітної плати. Максимальний дохід має бути менше 1,5 млн і число найманих працівників не повинно перевищувати 10 осіб.

3. Єдиний податок третя група - 3\%, 5\%. Гранична сума доходу на рівні 5 млн й відсутні обмеження щодо працівників [11]. 
Окрім згаданих відрахувань, суб'єкту господарської діяльності також слід сплатити 20\% ПДВ, що накладається на споживачів та впливає на загальну вартість продукції чи послуги, що в результаті впливає на попит.

Податок з обороту становить 20\%, але є список товарів на які застосовується знижена податкова ставка 7\% (фармацевтична продукція).

Податок на прибуток становить 18\%, виплати з дивідендів - 5\% [11].

На сучасному етапі за підрахунками міжнародної консалтингової компанії Pwc Україна займає 43 позицію в рейтингу податкового навантаження, кількість платежів мінімальна, всього 5 проти 8 в Естонії, чи 7 у Казахстані. Якщо ж звернути увагу на витрати часу на оплату податку, то майже усі країни пост-радянського простору виграють, за винятком Болгарії, проте Болгарія займає значно вищі позиції в рейтингу легкості ведення бізнесу. Проте ще у 2004p. витрати часу на сплату податків становили близько 2085 год, тобто майже у 10 разів показник скоротився, що вплинуло на позиції країни у Рейтингу.

Таблиця 2

Основні показники та позиції країн-сусідів та країн пострадянського простору у міжнародному рейтингу податкового навантаження за версією Pwc [2,10]

\begin{tabular}{|c|c|c|c|c|}
\hline Країна & $\begin{array}{c}\text { Місце у } \\
\text { рейтингу }\end{array}$ & $\begin{array}{c}\text { Загальний } \\
\text { відсоток } \\
\text { податків }\end{array}$ & $\begin{array}{c}\text { Кількість } \\
\text { платежів }\end{array}$ & $\begin{array}{c}\text { Витрати часу } \\
\text { на оплату } \\
\text { податків }\end{array}$ \\
\hline Естонія & 14 & $48,7 \%$ & 8 & 50 \\
\hline Молдова & 32 & $40,5 \%$ & 10 & 181 \\
\hline Росія & 52 & $47,5 \%$ & 7 & 167 \\
\hline Україна & 43 & $37,8 \%$ & 5 & 328 \\
\hline Казахстан & 56 & $29,4 \%$ & 7 & 182 \\
\hline Білорусь & 96 & $52,9 \%$ & 11 & 184 \\
\hline Болгарія & 90 & $27,1 \%$ & 14 & 453 \\
\hline
\end{tabular}

Протягом останніх років була проведена низка реформ, що скоротила кількість податків та необхідних звітів й впроваджено електронну систему звітностей, що не аби як скоротило витрати часу на сплату.

Ставки податків також грають роль (Таб.3), оскільки невелика кількість податків, може бути затьмарена розміром обов'язкових платежів, що також впливає на позиції країни у рейтингу. Високі ставки податків збільшують відсоток тіннізації економіки, оскільки підприємства прагнуть до максимізації прибутку й вдаються до ведення чорної бухгалтерії.

Таблиця 3

Податкові ставки в країнах-сусідах та країнах пострадянського простору [12]

\begin{tabular}{|c|c|c|c|c|}
\hline Країна & $\begin{array}{c}\text { Корпоративний } \\
\text { податок }\end{array}$ & $\begin{array}{c}\text { Податок на } \\
\text { дохід (мін) }\end{array}$ & $\begin{array}{c}\text { Податок на } \\
\text { дохід (макс) }\end{array}$ & ПДВ \\
\hline Білорусь & $18 \%$ & $13 \%$ & $17 \%$ & $20 \%$ \\
\hline Естонія & $0 \%$ & $20 \%$ & $20 \%$ & $0 \% 9 \% 20 \%$ \\
\hline Молдова & $12 \%$ & $12 \%$ & $12 \%$ & $10 \% 20 \%$ \\
\hline Росія & $20 \%$ & $13 \%$ & $47 \%$ & $20 \%$ \\
\hline Україна & $18 \%$ & $18 \%$ & $18 \%$ & $0 \%, 7 \%, 20 \%$ \\
\hline Грузія & $0 \%$ & $20 \%$ & $20 \%$ & $18 \%$ \\
\hline Болгарія & $10 \%$ & $10 \%$ & $28 \%$ & $20 \%$ \\
\hline
\end{tabular}


Не зважаючи на те, що позиції України в рейтингу легкості ведення бізнесу покращилися на 20 позицій за останні 3 роки, в порівнянні з країнами пострадянського простору, Україна займає порівняно низькі позиції (таб.4). Одним 3 важелів при підрахуванні індексу є система оподаткування, при високих ставках податку страждає малий та середній бізнес, що становить основу економіки країни. Можна провести паралель між податковим навантаженням за місцем країн в рейтингу ведення бізнесу. Нульовий корпоративний податок та перелік продукції що не оподатковується допомогли Естонії посісти гідне 12 місце у 2018 році. Аналогічну ситуацію ми можемо спостерігати і в інших країнах, де податкові ставки на порядок нижчі, позиції у рейтингу вищі відповідно.

Таблиця 4

Позиції країн в рейтингу легкості ведення бізнесу 2006-2018 pp. [2,10]

\begin{tabular}{|c|c|c|c|c|c|}
\hline Країна & $\mathbf{2 0 0 6}$ & $\mathbf{2 0 0 9}$ & $\mathbf{2 0 1 2}$ & $\mathbf{2 0 1 5}$ & $\mathbf{2 0 1 8}$ \\
\hline Естонія & 18 & 22 & 24 & 17 & 12 \\
\hline Казахстан & 86 & 70 & 47 & 77 & 36 \\
\hline Україна & 124 & 142 & 154 & 96 & 76 \\
\hline Росія & 95 & 118 & 120 & 62 & 35 \\
\hline Білорусь & 107 & 82 & 69 & 57 & 38 \\
\hline Молдова & 69 & 108 & 81 & 63 & 44 \\
\hline Болгарія & 48 & 42 & 59 & 38 & 50 \\
\hline
\end{tabular}

Якщо розглядати Естонію, то в країні відсутній податок на дохід підприємства, що практично робить країну оншорною. Проте власники мають сплатити $20 \%$ податок на додану вартість або знижену ставку - 9\% (медикаменти, книги, квитки на вистави і інше). У випадку виробництва експортно орієнтованої продукції, ставка дорівнює 0\%, що збільшує конкурентоспроможність продукції на міжнародному ринку. В Україні занижена ставка у розмірі 7\% розповсюджується лише на медикаменти та медичне обладнання [1].

Дохід з дивідендів оподатковується на 0 \% від його обсягу, ставка корпоративного податку $21 \%$. Приватні особи сплачують податок у розмірі $21 \%$, якщо не здійснюється реінвестування в розвиток бізнесу [5].

Мінімальна заробітна плата в Естонії з 01.01.2018 становить 500 євро, що дорівнює неоподаткованому мінімуму податку на доходи [5].

Процедура відкриття бізнесу займає всього близько 1 години, та не потребує перебування особи на території країни та проводиться онлайн, податки також сплачуються через відповідні онлайн-сервіси, що значно економить час підприємців та дозволяє країні оптимізувати витрати ВВП на 2-3\% щорічно, на веденні документації та відсутності необхідності відповідного персоналу [1].

Естонія не зупинилася на досягнутому, вона створила спеціальну платформу, на якій житель будь-якої країни може отримати Е-резиденцію, що дозволяє відкрити бізнес в країні, навіть знаходячись поза межами країни. У 2017 році близько 28000 осіб скористалися сервісом з 148 країн, з України, зокрема, звернулося 1554 особи, що створили 288 підприємств [1].

Соціальний внесок з 01.01.2018 в Естонії становить 33\%, в Україні цей показник становив - 34,7\% до 2015 року включно, з 01.01.2016 - 22\% [6]. 
В Казахстані корпоративний податок - 20\%, проте сільськогосподарські угіддя сплачують знижену ставку - 10\%.Індивідуальний податок становить 5-10\% здебільшого. Податок на додану вартість всередині Казахстану відсутній, його застосовують лише при імпортуванні й становить він $12 \%$. Саме таким чином країна захищає вітчизняного виробника, проте все ж відносно невисока ставка стимулює роботу місцевих підприємств

Соціальний податок становить 9,5\%,що вдвічі менше ніж в Україні та у майже 3,5 разів менше ніж у Естонії. Відрахування до пенсійного фонду становлять $10 \%$.

В Казахстані існує 6 систем нарахування податків, проте основними $є$ також загальна система та спрощена система оподаткування - спеціальний податковий режим [8].

Спеціальний податковий режим включає в себе 3 підтипи (табл. 5)

Таблиця 5

Підтипи спеціального податкового режиму у Казахстані [13]

\begin{tabular}{|c|c|c|c|}
\hline Дохід & На основі патента & $\begin{array}{c}\text { На основі } \\
\text { спрощеної } \\
\text { декларації }\end{array}$ & $\begin{array}{c}\text { Режим фіксованих } \\
\text { відрахувань }\end{array}$ \\
\hline $\begin{array}{c}\text { Ке більше 8 485 } \\
200 \text { тенге } \\
\text { (бл.644 тис. грн) }\end{array}$ & $\begin{array}{c}\text { Не більше } 57812 \\
496 \text { тенге } \\
\text { (бл.4,4 млн грн) }\end{array}$ & $\begin{array}{c}\text { Не більше } 346761 \\
840 \text { тенге (бл. } 26, \\
\text { млн грн.) }\end{array}$ \\
\hline працівників & - & Не більше 30 & Не більше 50 \\
\hline Відрахування & $\begin{array}{c}1 \% \text { ( в торгівлі }- \\
2 \%)\end{array}$ & $3 \%$ & $20 \%$ \\
\hline
\end{tabular}

Для сільських господарств встановлені ставки на рівні $30 \%$ від загальноприйнятих [13]. У Естонії ПДВ на сільськогосподарську продукцію становить $9 \%$.

В Україні виробники сільськогосподарської продукції включенні до системи спрощеного оподаткування. Останніми роками податкове навантаження на аграрний бізнес посилилося, що було зроблено у відповідності до вимог МВФ.

Така позиція зі сторони держави вражає, оскільки сільське господарство становить основу внутрішнього валового продукту, та також становить левову частку експорту країни, що забезпечує постійні валютні потоки до країни та зміцнює національну валюту (Таб.6).

Таблиця 6

Частка сільського господарства у ВВП України 2010-2016 рр. (в млн.грн) *

\begin{tabular}{|c|c|c|c|c|c|c|c|c|}
\hline Показник & $\mathbf{2 0 1 0}$ & $\mathbf{2 0 1 1}$ & $\mathbf{2 0 1 2}$ & $\mathbf{2 0 1 3}$ & $\mathbf{2 0 1 4}$ & $\mathbf{2 0 1 5}$ & $\mathbf{2 0 1 6}$ & $\mathbf{2 0 1 7}$ \\
\hline $\begin{array}{c}\text { Сільське } \\
\text { господарств } \\
\text { о }\end{array}$ & 189373 & 253485 & 261707 & 306998 & 381227 & 558788 & 655569 & 717192 \\
\hline ВВП & $\begin{array}{c}107934 \\
6\end{array}$ & $\begin{array}{c}129999 \\
1\end{array}$ & $\begin{array}{c}140466 \\
9\end{array}$ & $\begin{array}{c}146519 \\
8\end{array}$ & $\begin{array}{c}158691 \\
5\end{array}$ & $\begin{array}{c}198854 \\
4\end{array}$ & $\begin{array}{c}238536 \\
7\end{array}$ & $\begin{array}{c}298292 \\
0\end{array}$ \\
\hline $\begin{array}{c}\text { Частка С/Г } \\
\text { у ВВП }\end{array}$ & $17,5 \%$ & $19,5 \%$ & $18,6 \%$ & $20,9 \%$ & $24 \%$ & $28,1 \%$ & $27,5 \%$ & $24,04 \%$ \\
\hline
\end{tabular}

*побудовано автором відповідно на основі даних [4,9] 
Така позиція уряду сприяє монополізації ринку, оскільки великі аграрні холдинги та компанії зміцнять свої позиції на ринку й поглинуть малі підприємства, так як останні не зможуть витримати такий тиск й будуть змушені продавати чи здавати в аренду свої землі.

Уряд вирішив надати державні дотації сільгоспвиробникам у зв'язку з цим на період 31 січня 2017 року по 1 січня 2022 року, щоб хоч якось підтримати малі та середні підприємства. У 2017p. видатки у відповідності до програми дотацій становили 3,7 млрд. грн , що передбачає підтримку розвитку на фоні здешевлення кредитів, надання кредитів та фінансової допомоги, підтримку в тваринництві, виноградників та садоводств, проте такі підприємства мають бути внесені до реєстру отримувачів бюджетної дотації відповідно до Закону «Про державну підтримку сільського господарства України» [3].

Також у період 31 січня 2017 року по 1 січня 2022 року фермери звільняються від сплати податку на додану вартість, якщо вони внесені до реєстру [3].

У країнах Європи, наприклад, сільське господарство хоч і входить у загальну систему оподаткування, проте все ж отримує пільги. В Польщі фермери сплачують сільськогосподарський податок, замість податку на прибуток. Розмір такого специфічного податку встановлюється у відповідності 3 площею ділянки, на якій провадиться діяльність [7].

Загалом діє знижена ставка ПДВ у ряді Європейських країн (табл. 7).

Пільгові податкові ставки в країнах Свропи*

\begin{tabular}{|c|c|c|c|}
\hline Країни & $\begin{array}{c}\text { Максимально } \\
\text { знижена ставка } \\
\text { ПДВ }\end{array}$ & $\begin{array}{c}\text { Знижена ставка } \\
\text { ПДВ }\end{array}$ & $\begin{array}{c}\text { Стандартна ставка } \\
\text { ПДВ }\end{array}$ \\
\hline Іспанія & $4 \%$ & $10 \%$ & $21 \%$ \\
\hline Німеччина & - & $7 \%$ & $19 \%$ \\
\hline Естонія & - & $9 \%$ & $20 \%$ \\
\hline Франція & $2,1 \%$ & $5,5 \% / 10 \%$ & $20 \%$ \\
\hline Люксембург & $3 \%$ & $8 \%$ & $17 \%$ \\
\hline Італія & $4 \%$ & $5 \% / 10 \%$ & $22 \%$ \\
\hline
\end{tabular}

* побудовано автором на основі даних [7]

У податковому кодексі слід відвести розділ для пільг, що значно полегшить ведення бізнесу. Існує багато підходів до цього питання в світовій практиці, проте на основі проаналізованих країн можна виділити наступні аспекти:

- скасування податку на реінвестований прибуток в розвиток;

- зменшення ставки на прибуток підприємства, за умови реінвестиції;

- податкові канікули;

- зниження податкової ставки;

• відміна податку на безготівкові розрахунки.

Доцільно було б ввести регресивну шкалу оподаткування. Переважна більшість розвинених країн має диверсифіковану систему оподаткування, що передбачає сплату податку у відповідності до прибутку.

Важливо змусити підприємства проводи всі операції онлайн, таким чином процеси стали б більш прозорими та дозволили б мінімізувати вихід діяльності фірм у тінь.

Важливим кроком також було б запровадження правової бази для створення кластерів - сукупності малих та середніх підприємств об'єднаних однією метою, результатом діяльності яких є виготовлення якісного продукту. Кластери забезпечили б 
певну частину населення роботою, а також за нульової ставки, сприяло б розвитку об’єднання, його укрупненню та ефективності діяльності.

Таким чином, уряду країни слід зосередити основну увагу на виведені бізнесу з тіні, що в результаті забезпечило значні надходження в бюджет країни, що дозволило б зменшити податковий тиск на бізнес, так як і на населення в цілому. Наступні кроки мають бути направлені на стабілізацію економіки, заохочення населення до ведення господарської діяльності та підтримання середнього та малого бізнесу, шляхом податкових канікул та відсутністю податку на реінвестування прибутку в розвиток підприємств. Прийняття режиму найбільшого сприяння веденню господарської діяльності, привабило б також іноземний капітал та довело готовність країни до серйозних інвестицій та міжнародної співпраці з на зовнішніх ринках.

Висновки. Податкова система України має ряд переваг, проте значним ії̈ недоліком $\epsilon$ те, що вона носить здебільшого фіскальний характер. Влада для того аби наповнити бюджет з кожним разом збільшує податковий натиск на підприємства шляхом встановлення високих ставок та ускладненням податкових платежів. Таке $є$ явище $\epsilon$ негативним, оскільки штовхає бізнесменів до виплати зарплат у конвертах та ведення чорної бухгалтерії. Окреме місце займає спрощена система оподаткування, у якій ставки як для приватних підприємців так і для середніх підприємств майже однакові, не зважаючи на колосальну різницю в доходах. Сільське господарство, в свою чергу, займає пільгове місце в податкових системах провідних економік світу, проте в Україні для нього не існує специфічних ставок.

Перше, що необхідно зробити в Україні це вдосконалити механізм контролю та запровадити чіткі правила покарань підприємств, що ухиляються від сплати чи виводять кошти у «тінь». Подальші кроки повинні стосуватися зниження податкових ставок та диверсифікації груп оподаткування, необхідно зобов'язати підприємства фіксувати усі транзакції та заохочувати їх до ведення електронних розрахунків. 3 іншого боку, слід зосередитися на процедурі створення бізнесу, та покращити позиції у світовому рейтингу 3 ведення бізнесу. По-друге, створити спеціальні умови для підтримання сільського господарства та сприяти оновленню технологій в даній сфері, що б значно збільшило якість продукції і дозволило експортувати уже готову конкурентоспроможну продукцію на світовий ринок.

По-третє необхідно підтримувати бажання підприємств вкладати прибуток у розширення або розвиток виробництва, шляхом встановлення нульової ставки або ж встановити такий податок на 2 роки, для того аби підприємство змогло ефективно функціонувати і затвердитися на ринку країни.

\section{СПИСОК ВИКОРИСТАНИХ ДЖЕРЕЛ}

1. Барткова К.М Досвід Естонії в Українських реаліях //Збірник праць - том 2 Вінниця: ДонНУ імені Василя Стуса, 2018 - С.215-218

2. Барткова К.М Національне планування: чому українська стратегія сталого розвитку не $\epsilon$ дієвою? / Катерина Барткова//Формування ринкових відносин в Україні: Збірник наукових праць Вип. 9 (208). - К.,2018 - с.106-111

3. Бурковська А.В Сучасні особливості оподаткування сільськогосподарських підприємств України [Електронний ресурс]/ А. Бурковська // «Modern Economics» №6 (2017) c. 24-30 - Режим доступу до ресурсу: https://modecon.mnau.edu.ua/issue/62017/UKR/burkovskaya.pdf

4. Державна служба статистики України - Режим доступу до ресурсу: http://www.ukrstat.gov.ua 
5. Налоги в Эстонии в 2018 году - Ruber Zeppelin // [Електронный ресурс] URL: https://estoniancompany.eu/poleznoe/nalogi-v-estonii-v-2018-m-godu

6. Налоговые изменения в Эстонии с 2018 года - Campio group ( law\&consulting) // [Електронный ресурc] URL: https://www.campiogroup.com/news/2018/nalogovaya-2018/

7. Найбільш вигідні з точки зору податків країни Європи // [Електронний ресурс] URL: https://uteka.ua/ua/publication/news-14-delovye-novosti-36-naibolee-vygodnye-stochki-zreniya-nalogov-strany-evropy

8. ЮРИСТ - комплекс правовой информации (законодательство) Республики Казахстан // [Електронный ресурс] URL: https://online.zakon.kz

9. Офіційний сайт Міністерства Фінансів України - Режим доступу до ресурсу: https://minfin.com.ua/ua/

10. Офіційний сайт Світового банку - Режим доступу до ресурсу: http://www.doingbusiness.org/en/rankings

11. Податковий кодекс України - Режим доступу до ресурсу: http://sfs.gov.ua/nk/

12. Ткачик Л. П., Бешко О. Я. Спрощена система оподаткування як інструмент агресивного податкового планування [Електронний ресурс]/ Л. Ткачик, О. Бешко// «Молодий вчений» №2 (54) лютий, 2018 р. с. 758 - 763 - Режим доступу до ресурсу: http://molodyvcheny.in.ua/files/journal/2018/2/175.pdf

13. УЧЁТ.kz - Налоги в Казахстане // [Електронный ресурс] URL: https://uchet.kz/week/nalogi-v-kazakhstane/ 